Vedran Mrzljak

Igor Poljak

Vedran Medica-Viola

http://dx.doi.org/10.21278/brod68204

ISSN 0007-215X

eISSN 1845-5859

\title{
THERMODYNAMICAL ANALYSIS OF HIGH-PRESSURE FEED WATER HEATER IN STEAM PROPULSION SYSTEM DURING EXPLOITATION
}

\author{
UDC 629.5.016.7:629.5629.5.048.73 \\ Preliminary communication
}

\begin{abstract}
Summary
Nowadays diesel engines prevail as ship propulsion. However, steam propulsion is still primary drive for LNG carriers. In the presented paper high-pressure feed water heater was analyzed, as one of the essential components in LNG carrier steam propulsion system. Measurements of all operating parameters (fluid streams) at the analyzed heat exchanger inlets and outlets were performed. Change of the operating parameters was measured at different steam system loads, not at full load as usual. Through these measurements was enabled the insight into the behaviour of the heat exchanger operating parameters during the whole exploitation. The numerical analysis was performed, based on the measured data. The changes in energy and exergy efficiency of the heat exchanger were analyzed. Energetic and exergetic power inputs and outputs were also calculated, which enabled an insight into the change of energetic and exergetic power losses of the heat exchanger at different steam system loads. Change in energetic and exergetic power losses and operating parameters, which have the strongest influence on the highpressure feed water heater losses, were described. Analyzed heat exchanger was compared with similar heat exchangers in the base loaded conventional steam power plants. From the conducted analysis, it is concluded that the adjustment and control modes of these high-pressure heat exchangers are equal, regardless of whether they were mounted in the base loaded conventional steam power plants or marine steam systems, while their operating parameters and behaviour patterns differ greatly.
\end{abstract}

Key words: High-pressure feed water heater; Energy efficiency; Energetic power loss; Exergy efficiency; Exergetic power loss;

\section{Introduction}

Today, diesel engines are the dominant type of ship propulsion [1]. Although steam propulsion is overall only slightly present on ships, it is still dominant type of propulsion for LNG (Liquefied Natural Gas) carriers [2, 3]. Also, new systems for LNG carrier propulsion based on steam turbines are currently under the development [4]. One of the basic requirements that are nowadays placed in front of such propulsion systems is to reduce greenhouse gas emissions at the 
lowest possible level $[5,6]$. Any steam system is usually very complex because it is assembled from a large number of components $[7,8]$. Therefore, for the marine steam propulsion systems is necessary to conduct the economic analysis [9] and operation risk assessment [10] in order to minimize possible harmful consequences. Important elements of the steam plants are feed water heaters [11] regardless of the type and operation mode of the steam plant $[12,13]$. Usually, feed water heaters are shell and tube heat exchangers [14], but they also may occur as plate type heat exchangers [15]. This paper presents a thermodynamic analysis of a high-pressure shell and tube feed water heater, an important component in the analyzed steam propulsion system [16]. The role of this high-pressure heater is feed water heating before its entrance into the steam generator. Utilisation of high-pressure heater reduces fuel consumption, and thus enhances the efficiency of the entire propulsion system. Optimization of high-pressure feed water heater can be performed in different ways: with multi-objective genetic algorithm [17], artificial neural networks [18, 19] or with algorithm for economic optimization [20].

Flow, pressure and temperature measurements of operating fluids, passing through the analyzed heat exchanger, were conducted. The high-pressure feed water heater was investigated under transient operating conditions, during acceleration of the ship and its main propulsion propeller. The measurements were performed by using the existing measurement equipment, calibrated and mounted on inlets and outlets of each operating fluid. Energy and exergy efficiencies, as well as energetic and exergetic power losses of the observed heater were calculated by using the equations presented in the paper.

The main characteristics of the LNG carrier powered by the steam propulsion system, which contains the analyzed high-pressure feed water heater, are presented in Table 1.

Table 1 Main characteristics of the analyzed LNG carrier

\begin{tabular}{|l|c|}
\hline Dead weight tonnage & 84.812 DWT \\
\hline Overall length & $288 \mathrm{~m}$ \\
\hline Max breadth & $44 \mathrm{~m}$ \\
\hline Design draft & $9.3 \mathrm{~m}$ \\
\hline Steam generators & 2 x Mitsubishi MB-4E-KS \\
\hline Propulsion turbine & Mitsubishi MS40-2 (29420 kW) \\
\hline Turbo-generators & 2 x Shinko RGA 92-2 $(3850 \mathrm{~kW})$ \\
\hline $\begin{array}{l}\text { Steam turbine for main } \\
\text { feed water pump drive }\end{array}$ & Shinko DMG 125-3 $(570 \mathrm{~kW})$ \\
\hline
\end{tabular}

\section{Description and characteristics of analyzed high-pressure feed water heater}

Analyzed high-pressure feed water heater is shell and tube heat exchanger [21, 22]. Shell side contains the steam inlet and condensate outlet, while tube side contains the feed water inlet and outlet. The steam from the steam generator or from the main turbine is supplied to the heat exchanger shell. Heat is transferred from the steam to the feed water by convection and conduction through the tube walls. Due to the heat removal, the steam condenses on the outer tube walls. The condensate is drained from the heat exchanger.

The main construction and the operating parameters of analyzed high-pressure feed water heater (shell and tube side) are presented in Table 2, according to the producer specifications [23]. 
Heater in Steam Propulsion System during Exploitation

Table 2 Main construction and operating parameters of the analyzed high-pressure feed water heater

\begin{tabular}{|l|l|l|}
\hline $3^{\text {RD }}$ STAGE FEED WATER HEATER & SHELL SIDE & TUBE SIDE \\
\hline Maximum flow rate (kg/h) & 3728 & 121472 \\
\hline Maximum operating pressure (bar) & 7.355 & 86.5 \\
\hline Number of passes & 2 zones & 2 passes \\
\hline Velocity (m/s) & - & 1.6 at $137^{\circ} \mathrm{C}$ \\
\hline Maximum pressure drop (bar) & - & 0.17 \\
\hline Maximum corrosion allowance $(\mathrm{mm})$ & 1.6 & 1.6 \\
\hline Number of tubes & - & $150(\mathrm{U}$ tubes $)$ \\
\hline Tube outer diameter (mm) & - & 19.05 \\
\hline Shell inner/outer diameter (mm) & $660 / 678$ & - \\
\hline Material & SB410 (Carbon Steel) & A179 (Carbon Steel) \\
\hline Dry weight $(\mathrm{kg})$ & 3600 & 2100 \\
\hline
\end{tabular}

Process scheme of the steam propulsion system main components along with analyzed high-pressure feed water heater is presented in Figure 1. High-pressure feed water heater is exposed to the high loads during operation, so it is mandatory to perform its regular inspections and controls, similar to the highly loaded heat exchangers in the base loaded conventional steam power plants (term base loaded conventional steam power plants denote coal fired or nuclear power plants based on Rankine cycle) [24].

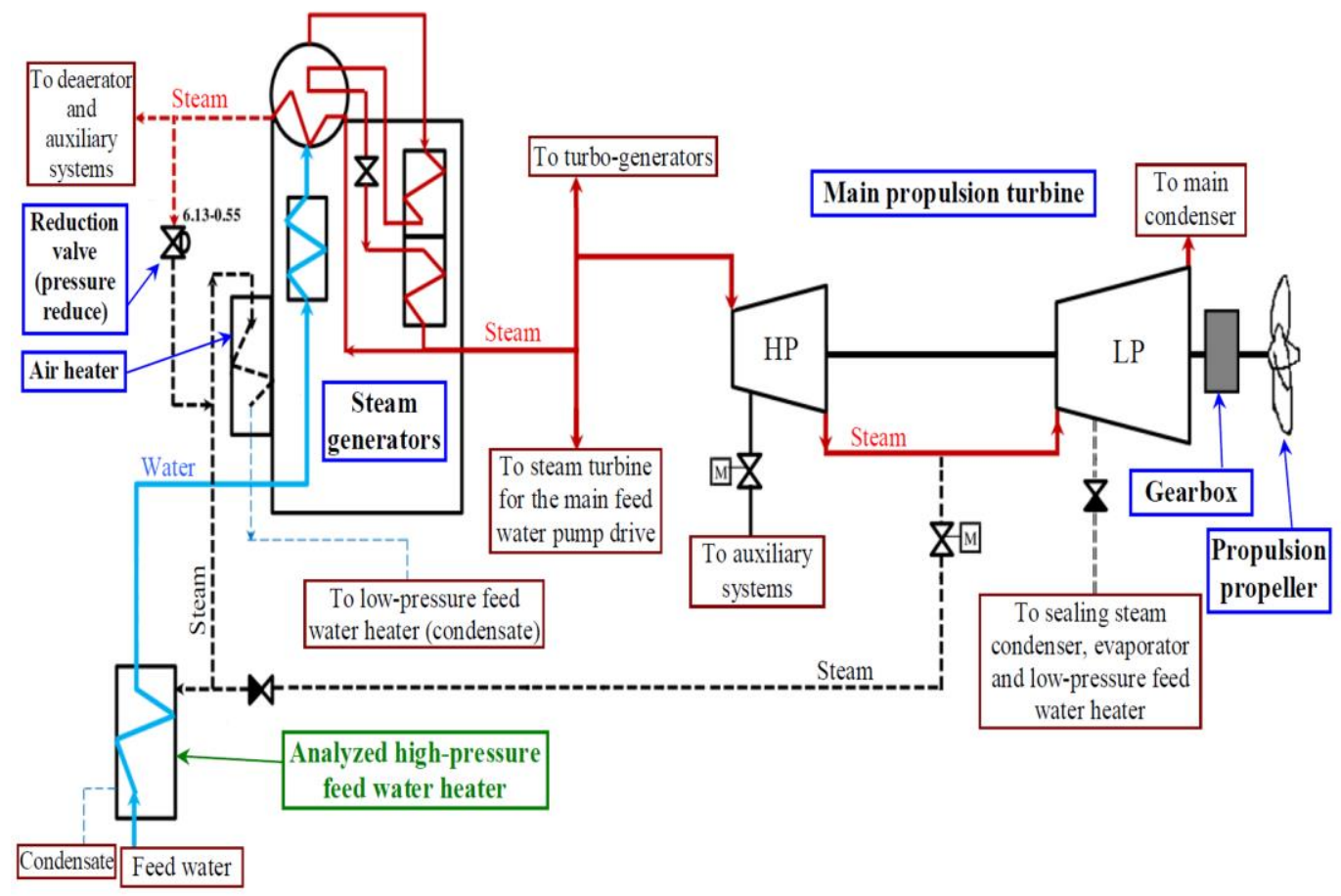

Figure 1 Process scheme of the steam propulsion system main components along with analyzed high-pressure feed water heater 


\section{Equations for energy and exergy analysis}

At the beginning of the presentation of equations it is important to explain the terms: energy efficiency, energetic power loss, exergy efficiency and exergetic power loss (exergy destruction).

Energy efficiency is based on the first law of thermodynamics [25]. It may take different forms and different names depending on the type of the system. Usually, energy efficiency can be written as:

$$
\eta_{\mathrm{en}}=\frac{\text { Energy output }}{\text { Energy input }}
$$

Energetic power loss is the difference between energetic power input and energetic power output [26]:

$$
\dot{E}_{\mathrm{en}, \mathrm{PL}}=\dot{E}_{\mathrm{en}, \mathrm{IN}}-\dot{E}_{\mathrm{en}, \mathrm{OUT}}=\dot{E}_{\mathrm{en}, \mathrm{IN}}\left(1-\eta_{\mathrm{en}}\right)
$$

The energetic power input is the amount of energy which has been supplied to the observed control volume, and energetic power output is the amount of energy which has been taken away from the observed control volume [27]. For any heat exchanger, energetic power input is defined by the power differences (input and output) of the operating fluid (steam) which conveys the heat and on the other side, energetic power output is defined by the power differences (input and output) of the operating fluid (feed water) on which the heat is transferred [28].

The definition of exergy efficiency is based on the second law of thermodynamics [29]. It is also called second law efficiency or effectiveness [30]. Exergy efficiency can be defined as:

$$
\eta_{\mathrm{ex}}=\frac{\text { Exergy output }}{\text { Exergy input }}
$$

Before defining the exergetic power loss (exergy destruction), it is necessary to define the exergy flow rate and specific exergy. The exergy flow rate of a flowing substance is the maximum rate of work that may be obtained from it, as it is transferred in a reversible way to the environmental state, exchanging heat and mass only with the surroundings [31]. In essence, exergy analysis defines the theoretical limitations imposed upon a system, clearly pointing out that no real system can conserve exergy and that only a portion of the input exergy can be recovered. In general, exergy is a thermodynamic indicator that shows the transformation potential and convertible limit of an energy carrier to maximum theoretical work under the limited conditions imposed by an environment at given pressure and temperature $[32,33]$.

The exergy flow rate is defined by an equation [34]:

$$
\dot{E}_{\mathrm{ex}, \mathrm{i}}=\dot{m}_{\mathrm{i}} \cdot \varepsilon_{\mathrm{i}}
$$

Specific exergy is defined according to [35] by an equation:

$$
\varepsilon_{\mathrm{i}}=\left(h_{\mathrm{i}}-h_{0}\right)-T_{0} \cdot\left(s_{\mathrm{i}}-s_{0}\right)
$$


Exergetic power loss or exergy destruction is the difference between exergy power input and exergy power output [36]:

$$
\dot{E}_{\mathrm{ex}, \mathrm{PL}}=\dot{E}_{\mathrm{ex}, \mathrm{IN}}-\dot{E}_{\mathrm{ex}, \mathrm{OUT}}=\dot{E}_{\mathrm{ex}, \mathrm{IN}}\left(1-\eta_{\mathrm{ex}}\right)
$$

Exergetic power input is the amount of exergy which has been supplied to the observed control volume, and exergetic power output is the amount of exergy which has been taken away from the observed control volume [26].

For the analyzed high-pressure feed water heater, all the essential elements for proper mathematical description were presented in Figure 2. The required enthalpies and entropies were calculated from measured pressures and temperatures for every of operating fluids by using NIST REFPROP software [37].

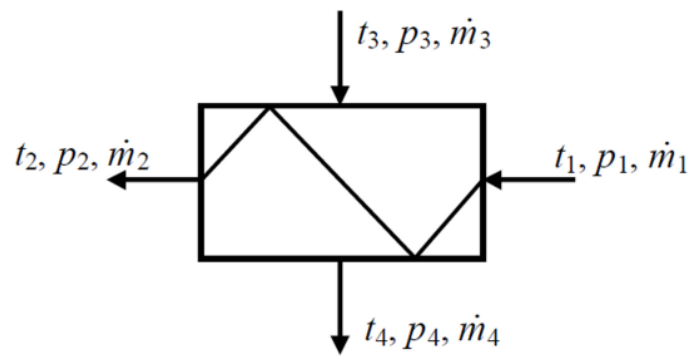

$$
\begin{aligned}
& 1=\text { feed water inlet } \\
& 2=\text { feed water outlet } \\
& 3=\text { steam inlet } \\
& 4=\text { condensate outlet }
\end{aligned}
$$

Figure 2 High-pressure feed water heater general symbol and main operating parameters

Mathematical definition of the analyzed high-pressure feed water heater, according to Figure 2, requires three balances which are necessary for energy and exergy efficiency and losses calculation. These balances are mass flow balance, energy balance and exergy balance [38].

3.1. High-pressure feed water heater mass flow balance

$$
\begin{aligned}
& \dot{m}_{1}=\dot{m}_{2} \\
& \dot{m}_{3}=\dot{m}_{4}
\end{aligned}
$$

3.2. High-pressure feed water heater energy balance

Energetic power input:

$$
\dot{E}_{\text {en, IN }}=\dot{m}_{3} \cdot\left(h_{3}-h_{4}\right)
$$

Energetic power output:

$$
\dot{E}_{\mathrm{en}, \mathrm{OUT}}=\dot{m}_{1} \cdot\left(h_{2}-h_{1}\right)
$$

Energetic power loss:

$$
\begin{aligned}
& \dot{E}_{\text {en,PL }}=\dot{E}_{\text {en,IN }}-\dot{E}_{\text {en,OUT }}= \\
& =\dot{m}_{3} \cdot\left(h_{3}-h_{4}\right)-\dot{m}_{1} \cdot\left(h_{2}-h_{1}\right)=\dot{m}_{3} \cdot h_{3}+\dot{m}_{1} \cdot h_{1}-\dot{m}_{3} \cdot h_{4}-\dot{m}_{1} \cdot h_{2}
\end{aligned}
$$


The energy efficiency of the high-pressure feed water heater was obtained by using an equation (12), according to [26, 35]:

$$
\eta_{\text {en }}=\frac{\dot{m}_{1} \cdot\left(h_{2}-h_{1}\right)}{\dot{m}_{3} \cdot\left(h_{3}-h_{4}\right)}
$$

3.3. High-pressure feed water heater exergy balance

Exergetic power input:

$$
\dot{E}_{\mathrm{ex}, \mathrm{IN}}=\dot{m}_{3} \cdot\left(\varepsilon_{3}-\varepsilon_{4}\right)
$$

Exergetic power output:

$$
\dot{E}_{\mathrm{ex}, \mathrm{OUT}}=\dot{m}_{1} \cdot\left(\varepsilon_{2}-\varepsilon_{1}\right)
$$

Exergetic power loss:

$$
\begin{aligned}
& \dot{E}_{\mathrm{ex}, \mathrm{PL}}=\dot{E}_{\mathrm{ex}, \mathrm{IN}}-\dot{E}_{\mathrm{ex}, \mathrm{OUT}}= \\
& =\dot{m}_{3} \cdot\left(\varepsilon_{3}-\varepsilon_{4}\right)-\dot{m}_{1} \cdot\left(\varepsilon_{2}-\varepsilon_{1}\right)=\dot{m}_{3} \cdot \varepsilon_{3}+\dot{m}_{1} \cdot \varepsilon_{1}-\dot{m}_{3} \cdot \varepsilon_{4}-\dot{m}_{1} \cdot \varepsilon_{2}
\end{aligned}
$$

The exergy efficiency of the high-pressure feed water heater was obtained by using an equation (16), according to $[39,40]$ :

$$
\eta_{\mathrm{ex}}=\frac{\dot{m}_{1} \cdot\left(\varepsilon_{2}-\varepsilon_{1}\right)}{\dot{m}_{3} \cdot\left(\varepsilon_{3}-\varepsilon_{4}\right)}
$$

The environment state (dead state) in the engine room of the analyzed LNG carrier during a measurement period was:

- pressure: $\quad p_{0}=0.1 \mathrm{MPa}$,

- temperature: $T_{0}=25^{\circ} \mathrm{C}=298.15 \mathrm{~K}$.

\section{Measuring equipment and measurement results}

The measurement results were obtained by using existing installed measuring equipment already calibrated and mounted on all components of the analyzed steam propulsion system. Control and maintenance system (provided by the manufacturer of the analyzed LNG carrier) is very important on such propulsion systems, because it enables safe control and adjustment of important operating parameters for each constituent component.

The high-pressure feed water heater measured data, as well as a list of used measuring equipment are presented in two parts: the first part refers to the feed water (inlet and outlet), while the second part refers to the steam (inlet) and condensate (outlet).

Table 3 presents measuring equipment used to acquire data of the feed water inlet and outlet of the analyzed high-pressure feed water heater.

Table 4 presents feed water measurement results (also at inlet and outlet). 
Table 3 Measuring equipment for feed water at the heat exchanger inlet and outlet

\begin{tabular}{|l|c|}
\hline $\begin{array}{l}\text { Feed water temperature at } \\
\text { the inlet and outlet }\end{array}$ & $2 \times$ Greisinger GTF 401-Pt100 - Immersion probe [41] \\
\hline $\begin{array}{l}\text { Feed water pressure at the } \\
\text { inlet and outlet }\end{array}$ & $2 \times$ Yamatake JTG960A - Pressure Transmitter [42] \\
\hline Feed water mass flow (inlet) & Promass 80F - Coriolis Mass Flow Measuring System [43] \\
\hline
\end{tabular}

Table 4 Measured results for feed water at the inlet and outlet of the analyzed heat exchanger

\begin{tabular}{|c|c|c|c|c|c|c|}
\hline $\begin{array}{c}\text { Measu- } \\
\text { rement } \\
\text { No. }\end{array}$ & $\begin{array}{c}\text { Propulsion } \\
\text { propeller } \\
\text { speed (rpm) }\end{array}$ & $\begin{array}{l}\text { Feed water } \\
\text { mass flow } \\
(\mathrm{kg} / \mathrm{h})\end{array}$ & $\begin{array}{c}\text { Feed water } \\
\text { pressure at } \\
\text { the heat } \\
\text { exchanger } \\
\text { inlet }(\mathrm{MPa}) \\
\end{array}$ & $\begin{array}{l}\text { Feed water } \\
\text { temperature } \\
\text { at the heat } \\
\text { exchanger } \\
\text { inlet }\left({ }^{\circ} \mathrm{C}\right) \\
\end{array}$ & $\begin{array}{c}\text { Feed water } \\
\text { pressure at } \\
\text { the heat } \\
\text { exchanger } \\
\text { outlet (MPa) }\end{array}$ & $\begin{array}{c}\text { Feed water } \\
\text { temperature } \\
\text { at the heat } \\
\text { exchanger } \\
\text { outlet }\left({ }^{\circ} \mathrm{C}\right)\end{array}$ \\
\hline 1 & 25.00 & 49834 & 7.57 & 127.30 & 7.57 & 146.00 \\
\hline 2 & 41.78 & 50385 & 7.59 & 127.30 & 7.59 & 146.00 \\
\hline 3 & 56.65 & 59193 & 7.79 & 127.30 & 7.79 & 145.00 \\
\hline 4 & 61.45 & 65692 & 7.66 & 126.30 & 7.66 & 144.00 \\
\hline 5 & 62.52 & 65350 & 7.85 & 126.30 & 7.85 & 144.00 \\
\hline 6 & 63.55 & 68988 & 7.64 & 126.20 & 7.64 & 144.00 \\
\hline 7 & 65.10 & 71852 & 7.61 & 126.20 & 7.61 & 144.00 \\
\hline 8 & 66.08 & 74165 & 7.58 & 126.20 & 7.58 & 144.00 \\
\hline 9 & 67.68 & 78028 & 7.53 & 126.20 & 7.53 & 144.00 \\
\hline 10 & 68.66 & 77723 & 7.55 & 125.10 & 7.55 & 143.00 \\
\hline 11 & 69.49 & 79662 & 7.48 & 125.00 & 7.48 & 143.00 \\
\hline 12 & 70.37 & 81447 & 7.50 & 124.00 & 7.50 & 143.00 \\
\hline 13 & 71.03 & 81827 & 7.49 & 123.00 & 7.49 & 142.00 \\
\hline 14 & 73.09 & 88350 & 7.62 & 122.00 & 7.62 & 141.00 \\
\hline 15 & 74.59 & 88330 & 7.60 & 123.90 & 7.60 & 141.00 \\
\hline 16 & 76.56 & 94236 & 7.48 & 124.80 & 7.48 & 141.00 \\
\hline 17 & 78.41 & 101167 & 7.36 & 124.80 & 7.36 & 140.00 \\
\hline 18 & 79.46 & 99381 & 7.52 & 127.00 & 7.52 & 140.00 \\
\hline 19 & 80.44 & 104148 & 7.48 & 127.00 & 7.48 & 140.00 \\
\hline 20 & 81.49 & 103518 & 7.46 & 126.00 & 7.46 & 140.00 \\
\hline 21 & 82.88 & 109302 & 7.37 & 127.00 & 7.37 & 140.00 \\
\hline 22 & 83.00 & 110663 & 7.38 & 127.00 & 7.38 & 140.00 \\
\hline
\end{tabular}

The second part of the analyzed high-pressure feed water heater refers to the steam at the heater inlet and condensate at the heater outlet. Table 5 presents used measuring equipment at the heater inlet and outlet for both steam and condensate.

Table 6 presents the corresponding measurement results. 
Table 5 Measuring equipment for steam and condensate at the heat exchanger inlet and outlet

\begin{tabular}{|l|l|}
\hline Steam temperature (inlet) & Greisinger GTF 401-Pt100 - Immersion probe [41] \\
\hline Steam pressure (inlet) & Yamatake JTG940A - Pressure Transmitter [42] \\
\hline Steam mass flow (inlet) & Yamatake JTD920A - Differential Pressure Transmitter [44] \\
\hline Condensate temperature (outlet) & Greisinger GTF 401-Pt100 - Immersion probe [41] \\
\hline Condensate pressure (outlet) & Yamatake JTG940A - Pressure Transmitter [42] \\
\hline
\end{tabular}

Table 6 Measurement results for steam and condensate at inlet and outlet of analyzed heat exchanger

\begin{tabular}{|c|c|c|c|c|c|c|}
\hline $\begin{array}{c}\text { Measu- } \\
\text { rement } \\
\text { No. }\end{array}$ & $\begin{array}{c}\text { Propulsion } \\
\text { propeller } \\
\text { Speed (rpm) }\end{array}$ & $\begin{array}{c}\text { Steam mass } \\
\text { flow (kg/h) }\end{array}$ & $\begin{array}{c}\text { Steam pressure } \\
\text { at the heat } \\
\text { exchanger inlet } \\
\text { (MPa) }\end{array}$ & $\begin{array}{c}\text { Steam } \\
\text { temperature at } \\
\text { the heat } \\
\text { exchanger inlet } \\
\text { ( } \mathbf{C} \text { ) }\end{array}$ & $\begin{array}{c}\text { Condensate } \\
\text { pressure at the } \\
\text { heat exchanger } \\
\text { outlet (MPa) }\end{array}$ & $\begin{array}{c}\text { Condensate } \\
\text { temperature at } \\
\text { the heat } \\
\text { exchanger } \\
\text { outlet }\left({ }^{\mathbf{C}} \mathbf{C}\right)\end{array}$ \\
\hline $\mathbf{1}$ & 25.00 & 1898 & 0.550 & 273.0 & 0.549 & 155.38 \\
\hline $\mathbf{2}$ & 41.78 & 1948 & 0.550 & 264.0 & 0.550 & 155.45 \\
\hline $\mathbf{3}$ & 56.65 & 2158 & 0.550 & 257.0 & 0.549 & 155.38 \\
\hline $\mathbf{4}$ & 61.45 & 2395 & 0.550 & 257.0 & 0.548 & 155.31 \\
\hline $\mathbf{5}$ & 62.52 & 2374 & 0.550 & 259.0 & 0.550 & 155.45 \\
\hline $\mathbf{6}$ & 63.55 & 2510 & 0.550 & 258.0 & 0.548 & 155.31 \\
\hline $\mathbf{7}$ & 65.10 & 2620 & 0.550 & 259.0 & 0.547 & 155.24 \\
\hline $\mathbf{8}$ & 66.08 & 2696 & 0.550 & 260.0 & 0.546 & 155.17 \\
\hline $\mathbf{9}$ & 67.68 & 2832 & 0.550 & 261.0 & 0.546 & 155.17 \\
\hline $\mathbf{1 0}$ & 68.66 & 2818 & 0.550 & 262.0 & 0.548 & 155.31 \\
\hline $\mathbf{1 1}$ & 69.49 & 2886 & 0.550 & 262.0 & 0.549 & 155.38 \\
\hline $\mathbf{1 2}$ & 70.37 & 3146 & 0.550 & 262.0 & 0.550 & 155.45 \\
\hline $\mathbf{1 3}$ & 71.03 & 3159 & 0.550 & 262.0 & 0.550 & 155.45 \\
\hline $\mathbf{1 4}$ & 73.09 & 3415 & 0.550 & 259.0 & 0.550 & 155.45 \\
\hline $\mathbf{1 5}$ & 74.59 & 2906 & 0.550 & 259.0 & 0.539 & 154.80 \\
\hline $\mathbf{1 6}$ & 76.56 & 2905 & 0.550 & 259.0 & 0.531 & 154.11 \\
\hline $\mathbf{1 7}$ & 78.41 & 2913 & 0.550 & 259.0 & 0.541 & 154.82 \\
\hline $\mathbf{1 8}$ & 79.46 & 2399 & 0.549 & 261.0 & 0.549 & 155.38 \\
\hline $\mathbf{1 9}$ & 80.44 & 2536 & 0.580 & 256.0 & 0.580 & 157.50 \\
\hline $\mathbf{2 0}$ & 81.49 & 2717 & 0.568 & 253.0 & 0.568 & 156.69 \\
\hline $\mathbf{2 1}$ & 82.88 & 2680 & 0.590 & 250.0 & 0.590 & 158.17 \\
\hline $\mathbf{2 2}$ & 83.00 & 2698 & 0.593 & 256.4 & 0.593 & 158.36 \\
\hline
\end{tabular}

\section{Results analysis for high-pressure feed water heater}

Changes in energy and exergy efficiency of the high-pressure feed water heater in relation to propulsion propeller speed in rpm (revolutions per minute) are presented in Figure 3. Propulsion propeller speed increase is directly proportional to the steam system load - higher propulsion propeller speed represents higher steam propulsion system load by cubic law.

Even at low steam system loads (at lower propulsion propeller speed) energy efficiency of the analyzed heat exchanger is very high and amounts approximately to $90 \%$. During the load 
increase, energy efficiency also increases. The largest increase in energy efficiency is visible at the propulsion propeller speed of $74.59 \mathrm{rpm}$, above which the energy efficiency reaches almost $100 \%$. Reason for this sudden increase is the change of the origin of the supplied superheated steam. The steam system is optimized in such a way that up to $74.5 \mathrm{rpm}$, the steam is supplied to the analyzed heat exchanger only from the steam generators through the reduction valve. Above $74.5 \mathrm{rpm}$, intense heating of the feed water before the analyzed high-pressure feed water heater occurs. Thus water temperature rises at its entrance. In this operating mode, the superheated steam is no longer supplied from the steam generators, but by subtracting it from the main propulsion turbine. Sudden increase in analyzed high-pressure feed water heater energy efficiency at $74.59 \mathrm{rpm}$ does not occur because of increase in steam temperature (Table 6) which remains constant as in measuring point before $(73.09 \mathrm{rpm})$. Energy efficiency increase is caused by a decrease in steam mass flow supplied to heat exchanger what significantly reduces the denominator in the equation (12). This appearance does not reduce the temperature of the feed water at the high-pressure feed water heater outlet, because the feed water is heated to a higher temperature before the entrance into the heat exchanger.

Exergy efficiency shows the same trend of change as energy efficiency. At the lower loads, exergy efficiency amounts to around $77 \%$, while at the highest measured loads it reaches almost $85 \%$. It can be therefore concluded that the analyzed heat exchanger has lower exergy efficiency in relation to the energy efficiency, but still, the values of exergy efficiency are acceptable, especially during the transient operation.

Both efficiencies show a trend of growth during the steam system load increase. Therefore, it can be expected that maximum efficiency will be achieved at the highest steam system load. Regardless of that, it is essential to understand the heat exchanger efficiency change at partial loads in order to find the optimal operating range.

Compared with the similar high-pressure feed water heaters in the base loaded conventional steam power plants [34, 35], the analyzed heater has clearly lower efficiency. The reason for this phenomenon lies in a few facts. The first is that any device analysis in the base loaded conventional steam power plants is usually performed at full load, where it is expected that the efficiencies of high-pressure feed water heater have the highest values. The analyzed LNG carrier is operating at propulsion propeller speed of $95 \mathrm{rpm}$ (full speed) during most of the navigation time. At such speed the steam system is at its highest load. High-pressure feed water heater measurements were not performed at maximum system load and thus neither was the numerical analysis performed for maximum load. Also, the ship's heat exchangers have to be flexible in operation at different steam system loads. That is the main reason for their reduced energy and exergy efficiency when compared with the similar heat exchangers in the base loaded conventional steam power plants. That is also the main reason for low utilisation of the steam systems as ship propulsion systems. 


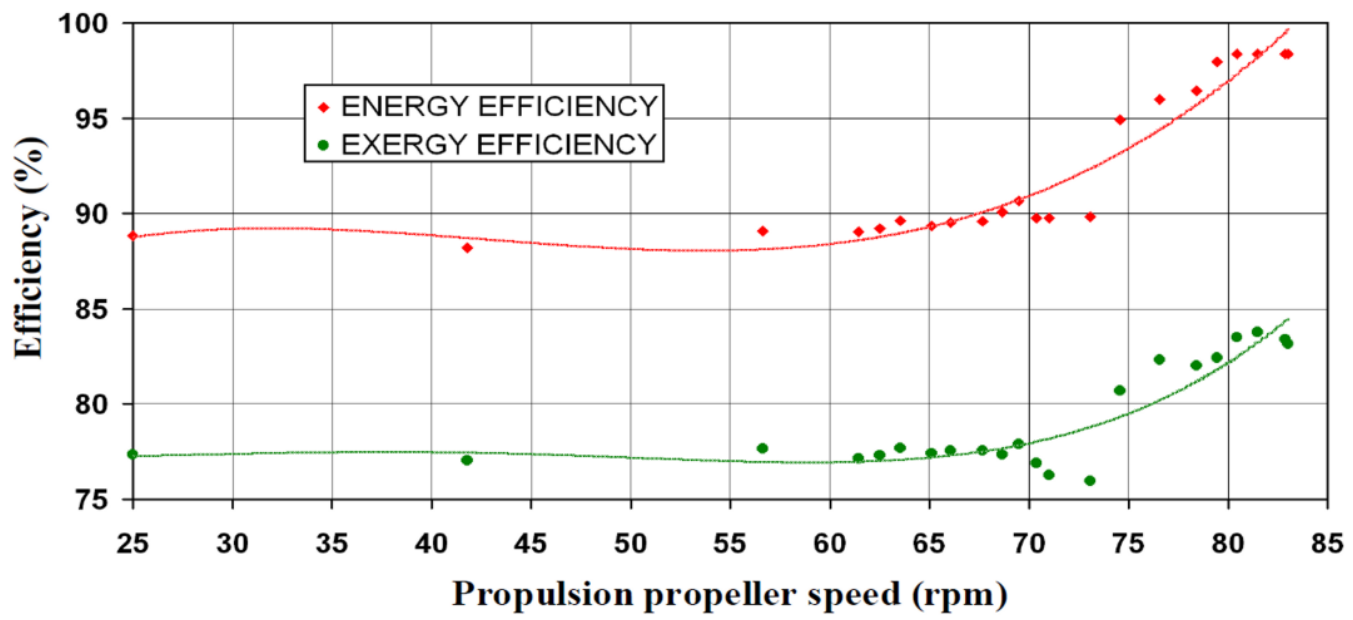

Figure 3 High-pressure feed water heater energy and exergy efficiency change

Outlet operating fluid (feed water and condensate) enthalpy changes for analyzed highpressure feed water heater is presented in Figure 4.

Temperature and enthalpy of the feed water at the heat exchanger outlet are constantly decreasing when the steam system load increase. Reduction in the temperature of the feed water output, which is the main reason for enthalpy drop, throughout the investigated area occurs in the steps of $1{ }^{\circ} \mathrm{C}$. The reason for this continuous temperature and enthalpy decrease is a constant feed water mass flow rate increase through the heat exchanger, during the steam system load increase. Although more steam (cumulative in all feed water heaters) was used for feed water heating at increased steam system load, the total heat flux transferred to the feed water was not sufficient to keep its outlet temperature on at least constant value.

The condensate enthalpy change at the high-pressure feed water heater outlet, Figure 4, shows an almost constant trend until the propulsion propeller reaches $74.59 \mathrm{rpm}$. At that point the condensate enthalpy starts to decrease, due to the decrease of condensate temperature (from $155.45^{\circ} \mathrm{C}$ at $73.09 \mathrm{rpm}$ to $154.8^{\circ} \mathrm{C}$ at $74.59 \mathrm{rpm}$ ). Enthalpy of the condensate starts to increase at the end of the observed steam system load range, when the condensate temperature rises above $156{ }^{\circ} \mathrm{C}$ (from $80.44 \mathrm{rpm}$ until the highest observed load at $83.00 \mathrm{rpm}$ ).

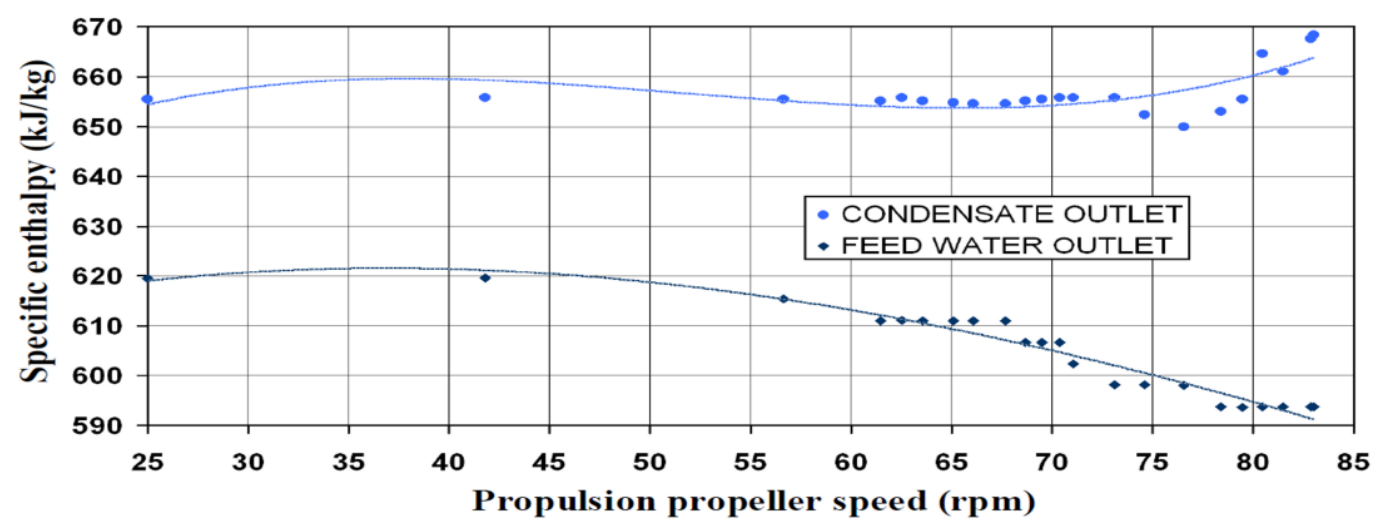

Figure 4 Change in enthalpy for outlets of feed water and condensate at the analyzed heat exchanger 
Energetic power input, Figure 5, shows that the amount of energy supplied to the high-pressure feed water heater constantly increases with an increase in steam system load. Such behaviour was expected, because system load increase causes also the supplied amount of steam to increase. Energetic power input increase lasts only until the steam system load at which the steam starts to be supplied from the main turbine. In the moment of steam supply from the main turbine (74.59 $\mathrm{rpm}$ ), steam mass flow reduces and energetic power input decrease. In the analyzed heat exchanger steam was not supplied simultaneously from the steam generators and from the main turbine. Steam supply was done from only one source at a time.

The energetic power output has the same trend of change as energetic power input, but with slightly lower values. It is important to notice that at the high end of the observed operating range, the trend lines of energetic power input and output are almost overlapping. The difference between these two curves represents the energetic power loss in the high-pressure feed water heater. Thus, it can be concluded that minimal energetic power losses occur at the highest observed steam system loads.

Low energetic power loss at the highest observed steam system load occurs due to the steam supply from the main turbine at such loads. When the steam is supplied from the main turbine, then the feed water is preheated more before entering into the analyzed heat exchanger. Because of that, at such loads, energetic power output decreases slower than energetic power input.

By observing Figure 5 it can be concluded that the energetic power loss can be reduced by proper adjustment of energetic power output, while reducing the energetic power input. In order to reduce the energetic power loss in the analyzed heat exchanger, it is necessary to achieve a good balance of the entire feed water system. Such balance would increase the high-pressure feed water heater energy efficiency, Figure 3, especially during the period of energetic power input decrease. During the said period, it is mandatory to achieve the necessary operating parameters at any moment. Therefore, in this operation mode, the effective control and regulation systems are of utmost importance [24].

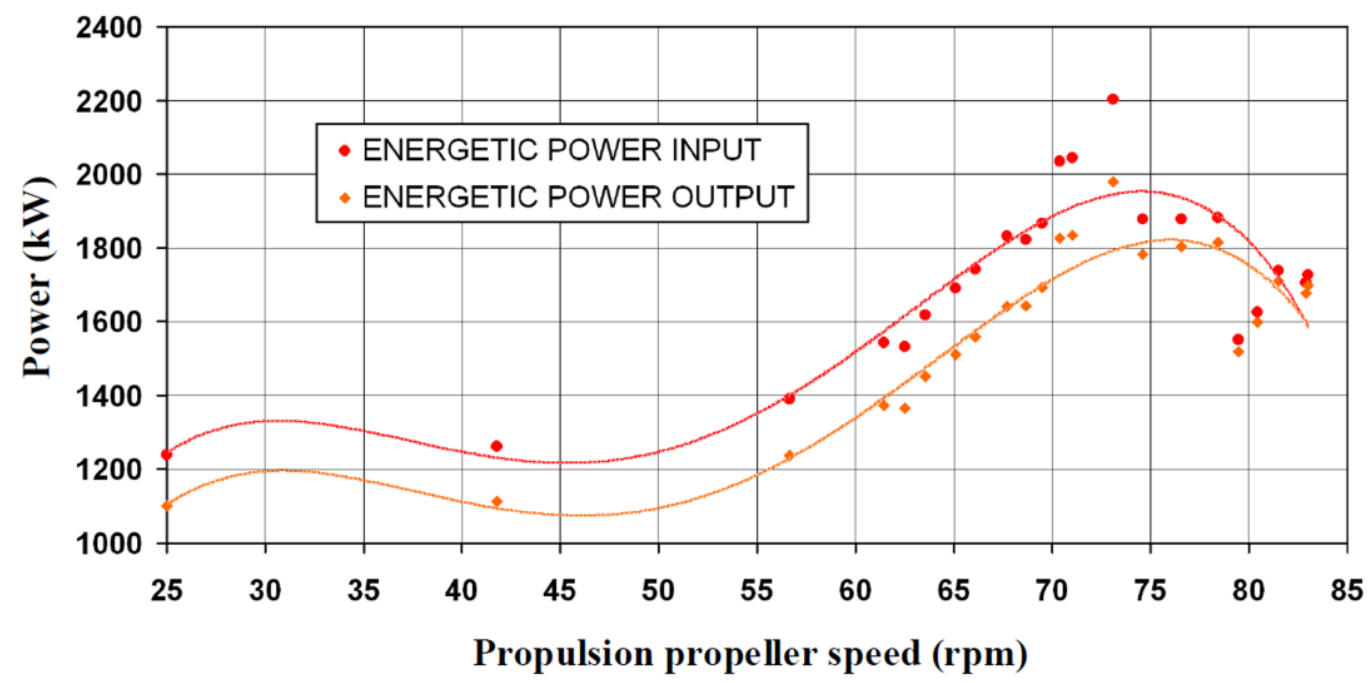

Figure 5 Energetic power input and output change in relation to propulsion propeller speed for the analyzed highpressure feed water heater 
The energetic power loss in the high-pressure feed water heater, for various propulsion propeller speeds, is presented in Figure 6.

At the propulsion propeller speed lower than $74.59 \mathrm{rpm}$, energetic power loss is significantly higher than the loss at higher steam system loads. This occurs because at lower steam system loads all feed water heat exchangers, including high-pressure feed water heater, are supplied with an unnecessarily large amount of energy in order to let every component achieve its desired operating temperature as fast as possible.

At propulsion propeller speeds higher than $74.59 \mathrm{rpm}$, the energetic power loss is significantly reduced, because the steam is supplied to the analyzed heat exchanger directly from the main turbine and its mass flow reduces. Accordingly, in this operating range a noticeable energetic power input reduction occurs, while the temperature of the feed water entering the highpressure heat exchanger increases.

The amount of energetic power loss in the analyzed heat exchanger is comparable with the data from [26], which contains the analysis results of the high-pressure feed water heaters in a base loaded conventional steam power plant. The comparison is possible only at the highest steam system loads. Compared with the heat exchangers from the base loaded conventional steam power plants, the heat exchanger analyzed in this paper has higher energetic power loss per unit of the exchanged heat, which can be justified by its greater flexibility. Such flexibility is one of the most important requirements for an efficient operation of any marine heat exchanger.

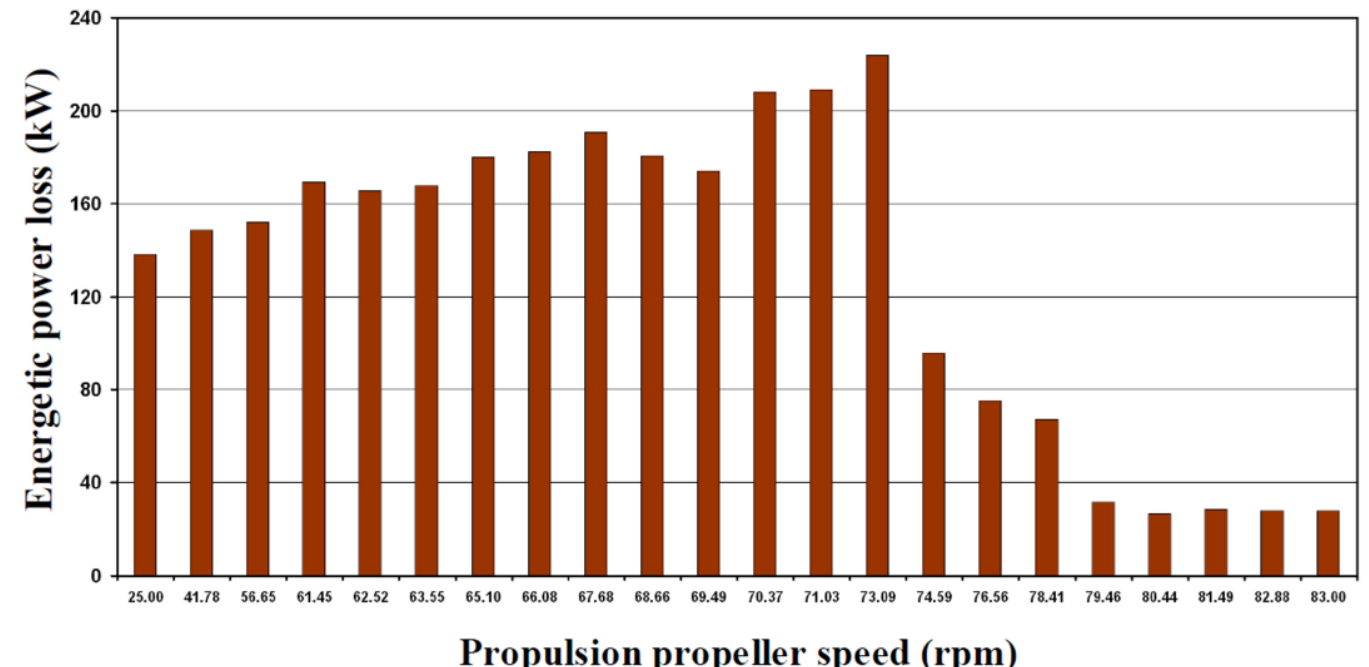

Figure 6 Energetic power loss change for the analyzed high-pressure feed water heater

Exergetic power input and output, Figure 7, shows similar behaviour to that of the energetic power input and output. Analyzed heat exchanger exergetic power input and output increase alongside with the steam system load increase, until the moment at which steam supply was switched from steam generators to the main propulsion turbine. At this point, a sharp decrease of exergetic power input occurs due to reduced steam mass flow, followed by a slightly milder decrease in exergetic power output. 


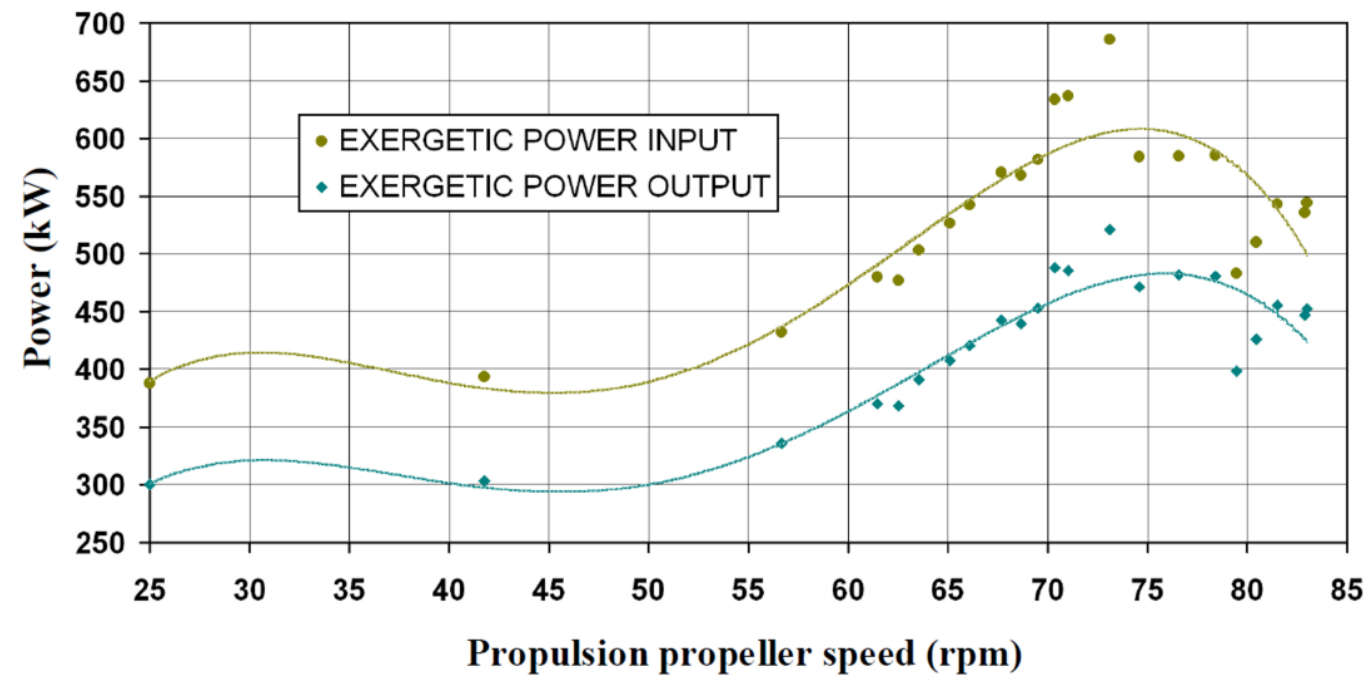

Figure 7 Exergetic power input and output change in relation to propulsion propeller speed for the analyzed highpressure feed water heater

In contrast to the behaviour of the energetic power input and output, trend lines of the exergetic power input and output approach each other at the highest analyzed steam system loads, but they do not come as close as do the trend lines of the energetic power input and output. This fact indicates that a sufficient amount of exergy is available in the analyzed heat exchanger also at the highest observed steam system loads. Exergetic power loss at propulsion propeller speeds higher than $74.59 \mathrm{rpm}$ is noticeably reduced, but the decrease is not as sharp as the decrease of energetic power loss in the same steam system load range.

The values of exergetic power loss at all observed propulsion propeller speeds, are presented in Figure 8.

The exergetic power loss trend is identical to energetic power loss trend, provided that when the steam starts to be supplied from the main turbine (when the steam mass flow reduces), a noticeable exergetic power loss decrease occurs. Although milder than the energetic power loss decrease at the same load range, it is still sufficient to significantly increase the exergy efficiency of the analyzed heat exchanger. The exergy efficiency is increased at the highest observed steam system loads.

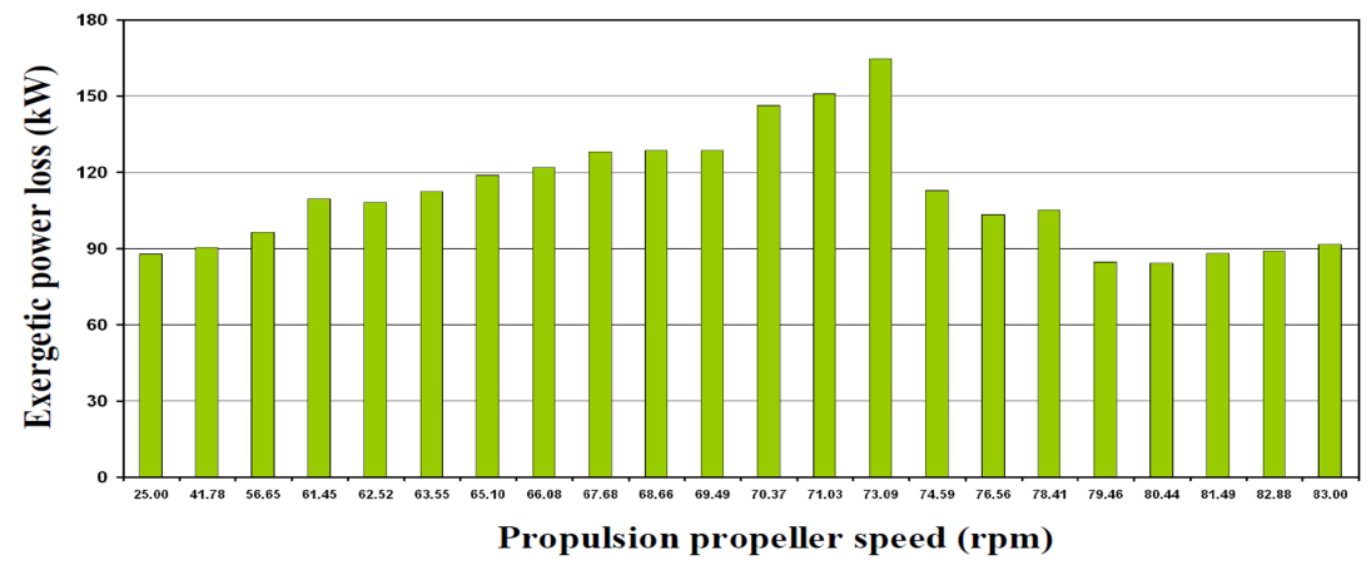

Figure 8 Exergetic power loss change for the analyzed high-pressure feed water heater 
When comparing the behaviour of energetic and exergetic power losses of the analyzed high-pressure feed water heater, it can be concluded that the trends are identical. On the other side, the intensity of changes noticeably differs throughout the observed operating range. The fluid flow rates and temperatures at the analyzed heat exchanger entrance have the greatest influence on energy and exergy efficiency. The highest energy and exergy efficiencies will be achieved at maximum steam system loads with the proper balancing of fluid flow rates and temperatures entering the heat exchanger.

\section{Conclusions}

In the presented paper a thermodynamic analysis of a high-pressure feed water heater installed in the LNG carrier steam propulsion system during exploitation was performed. Analysis is based on measured pressures, temperatures and mass flow rates for every inlet and outlet fluid stream throughout the high-pressure feed water heater. This heat exchanger was analyzed during the steam propulsion system load change, while the LNG carrier was manoeuvring, but did not reach the full speed.

Trends in energy and exergy efficiencies show that both efficiencies increases during the steam propulsion system load increase. At lower load, both efficiencies are maintained at almost constant values, but at the higher load efficiencies increase. This occurs due to the correct adjustment of the control and regulation system. The steam is the heating fluid in the observed exchanger. At lower steam system load, steam was supplied to the exchanger from the steam generators (through the reduction valve). At higher loads, it was supplied from the main turbine. Mass flow rate of the steam subtracted from the main turbine is lower than the mass flow rate of the steam supplied from the steam generators. Simultaneously, at the higher steam system load, higher steam mass flow rates are supplied to sealing steam condenser, low-pressure feed water heater and deaerator in order to increase the feed water temperature at the inlet of the highpressure feed water heater. Such regulation policy causes the analyzed heat exchanger energy and exergy efficiency to increase. Steam condensate temperature is the most influential parameter of which depends steam condensate enthalpy change. On the other side, the enthalpy of the feed water at the analyzed heat exchanger outlet is constantly decreasing, because its mass flow rate increases proportionally to the steam system load increase.

High-pressure feed water heater energetic power loss increases until the moment at which steam starts to be supplied from the main turbine instead from the steam generators. At that moment, due to decrease in steam mass flow rate, energetic power loss starts to decrease rapidly and is retained at low values until the highest observed steam system load. The trend of exergetic power loss is the same as the trend of energetic power loss. Exergetic power loss decrease is not as sharp as the energetic power loss decrease.

Compared with the high-pressure feed water heaters in the base loaded conventional steam power plants, the analyzed heat exchanger has higher energetic and exergetic power losses per unit of the exchanged heat. That is justified by the greater flexibility, necessary for the efficient operation of any marine heat exchanger.

From the viewpoint of energy and exergy, marine high-pressure feed water heaters and similar heaters from the base loaded conventional steam power plants are optimized in the same way - their losses are the smallest and efficiencies highest at the highest steam system load. The reason for such optimization is simple: most of the time high-pressure feed water heaters operate at maximum system load. 


\section{Acknowledgment}

The authors would like to extend their appreciations and gratitude to the main office of the analyzed LNG carrier ship-owner, for all the help during exploitation measurements and for ceded measuring equipment.

\section{NOMENCLATURE}

\section{Latin Symbols:}

$\dot{E} \quad$ flow power, $\mathrm{kW}$

$h \quad$ specific enthalpy, $\mathrm{kJ} / \mathrm{kg}$

$\dot{m} \quad$ mass flow, $\mathrm{kg} / \mathrm{s}$

p pressure, $\mathrm{MPa}$

$S$

$T$ specific entropy, $\mathrm{kJ} / \mathrm{kg} \cdot \mathrm{K}$ temperature, $\mathrm{K}$

\begin{tabular}{l|ll} 
& \multicolumn{2}{|l}{ Greek symbols: } \\
$\varepsilon$ & specific exergy, $\mathrm{kJ} / \mathrm{kg}$ \\
$\eta$ & efficiency, \% \\
& \multicolumn{2}{|l}{} \\
$\mathrm{kW}$ & Subscripts: & \\
0 & ambient state \\
$\mathrm{en} / \mathrm{s}$ & $\mathrm{eJ} / \mathrm{kg}$ & energy \\
$\mathrm{ex}$ & exergy \\
$\mathrm{K}$ & $\mathrm{i}$ & index for any fluid stream \\
& $\mathrm{IN}$ & input \\
& OUT & output \\
& PL & Power Loss
\end{tabular}

Greek symbols:

\section{REFERENCES}

[1] Zhao, F., Yang, W., Tan, W. W., Yu, W., Yang, J., Chou, S. K.: Power management of vessel propulsion system for thrust efficiency and emissions mitigation, Applied Energy 161, p. 124-132, 2016. (doi: 10.1016/j.apenergy.2015.10.022)

[2] LNG World Shipping Journal, September/October, 2007.

[3] Attah, E. E., Bucknall, R.: An analysis of the energy efficiency of LNG ships powering options using the EEDI, Ocean Engineering 110, Part B, p. 62-74, 2015. (doi: 10.1016/j.oceaneng.2015.09.040)

[4] Chang, D., Rhee, T., Nam, K., Chang, K., Lee, D., Jeong, S.: A study on availability and safety of new propulsion systems for LNG carriers, Reliability Engineering and System Safety 93, p. 1877- 1885, 2008. (doi: 10.1016/j.ress.2008.03.013)

[5] Schinas, O., Butler, M.: Feasibility and commercial considerations of LNG-fueled ships, Ocean Engineering 122, p. 84-96, 2016. (doi: 10.1016/j.oceaneng.2016.04.031)

[6] Senary, K., Tawfik, A., Hegazy, E., Ali, A.: Development of a waste heat recovery system onboard LNG carrier to meet IMO regulations, Alexandria Engineering Journal 55, Issue 3, p. 1951-1960, 2016. (doi: 10.1016/j.aej.2016.07.027)

[7] Fernández, I. A., Gómez, M. R., Gómez, J. R., Baaliña Insua, A. A.: Review of propulsion systems on LNG carriers, Renewable and Sustainable Energy Reviews 67, p. 1395-1411, 2017. (doi: 10.1016/j.rser.2016.09.095)

[8] Leyzerovich, A. S.: Steam Turbines for Modern Fossil-Fuel Power Plants, The Fairmont Press, Inc., 2008.

[9] Raj, R., Ghandehariun, S., Kumar, A., Geng, J., Ma, L.: A techno-economic study of shipping LNG to the Asia-Pacific from Western Canada by LNG carrier, Journal of Natural Gas Science and Engineering 34, p. 979-992, 2016. (doi: 10.1016/j.jngse.2016.07.024) 
[10] Vanem, E., Antao, P., Østvik, I., Del Castillo de Comas, F.: Analysing the risk of LNG carrier operations, Reliability Engineering and System Safety 93, p. 1328-1344, 2008. (doi: 10.1016/j.ress.2007.07.007)

[11] Yang, Y., Wang, L., Dong, C., Xu, G., Morosuk, T., Tsatsaronis, G.: Comprehensive exergy-based evaluation and parametric study of a coal-fired ultra-supercritical power plant, Applied Energy 112, p. 1087-1099, 2013. (doi: 10.1016/j.apenergy.2012.12.063)

[12] Peng, S., Wang, Z., Hong, H., Xu, D., Jin, H.: Exergy evaluation of a typical 330 MW solar-hybrid coal-fired power plant in China, Energy Conversion and Management 85, p. 848-855, 2014. (doi: 10.1016/j.enconman.2013.12.073)

[13] Kopac, M., Hilalci, A.: Effect of ambient temperature on the efficiency of the regenerative and reheat Catalagzi power plant in Turkey, Applied Thermal Engineering 27, p. 1377-1385, 2007. (doi: 10.1016/j.applthermaleng.2006.10.029)

[14] Yang, J. F., Lin, Y. S., Ke, H. B., Zeng, M., Wang, Q. W.: Investigation on combined multiple shell-pass shell-and-tube heat exchanger with continuous helical baffles, Energy 115, Part 3, p. 1572-1579, 2016. (doi: 10.1016/j.energy.2016.05.090)

[15] Cicek, K., Celik, M.: Selection of porous materials in marine system design: The case of heat exchanger aboard ships, Materials and Design 30, p. 4260-4266, 2009. (doi: doi:10.1016/j.matdes.2009.04.027)

[16] Ezgi, C., Özbalta, N., Girgin, I.: Thermohydraulic and thermoeconomic performance of a marine heat exchanger on a naval surface ship, Applied Thermal Engineering 64, p. 413-421, 2014. (doi: 10.1016/j.applthermaleng.2013.12.061)

[17] Daróczy, L., Janiga, G., Thévenin, D.: Systematic analysis of the heat exchanger arrangement problem using multi-objective genetic optimization, Energy 65, p. 364-373, 2014. (doi: 10.1016/j.energy.2013.11.035)

[18] Mohanraj, M., Jayaraj, S., Muraleedharan, C.: Applications of artificial neural networks for thermal analysis of heat exchangers - A review, International Journal of Thermal Sciences 90, p. 150-172, 2015. (doi: 10.1016/j.ijthermalsci.2014.11.030)

[19] Dudzik, S.: Investigations of a heat exchanger using infrared thermography and artificial neural networks, Sensors and Actuators A 166, p. 149-156, 2011. (doi: 10.1016/j.sna.2010.12.001)

[20] Mohanty, D. K.: Gravitational search algorithm for economic optimization design of a shell and tube heat exchanger, Applied Thermal Engineering 107, p. 184-193, 2016. (doi:10.1016/j.applthermaleng.2016.06.133)

[21] Kakac, S., Liu, H., Pramuanjaroenkij, A.: Heat Exchangers - Selection, Rating, and Thermal Design, Third edition, CRC Press, Taylor \& Francis Group, 2012.

[22] Serth, R. W., Lestina, T. G.: Process Heat Transfer - Principles, Applications and Rules of Thumb, Second edition, Elsevier Inc., 2014.

[23] $3^{\text {rd }}$ Feed Water Heater - instruction and maintenance manual, DongHwa Entec, Pusan, Korea, internal ship documentation, 2006.

[24] Annaratone, D.: Handbook for Heat Exchangers and Tube Banks Design, Springer, 2010. (doi: 10.1007/9783-642-13309-1)

[25] Moran, M. J., Shapiro, H. N.: Fundamentals of engineering thermodynamics, $6^{\text {th }}$ edition, John Wiley \& Sons, Hoboken, NJ, 2008.

[26] Adibhatla, S., Kaushik, S. C.: Energy and exergy analysis of a super critical thermal power plant at various load conditions under constant and pure sliding pressure operation, Applied Thermal Engineering 73, p. 4963, 2014. (doi: 10.1016/j.applthermaleng.2014.07.030)

[27] Taner, T., Sivrioglu, M.: Energy-exergy analysis and optimisation of a model sugar factory in Turkey, Energy 93, p. 641-654, 2015. (doi: 10.1016/j.energy.2015.09.007)

[28] Kaushik, S.C., Reddy, V.S., Tyagi, S.K.: Energy and exergy analyses of thermal power plants: A review, Renewable and Sustainable Energy Reviews 15, p. 1857-1872, 2011. (doi: 10.1016/j.rser.2010.12.007)

[29] Kanoğlu, M., Çengel, Y.A., Dincer, I.: Efficiency Evaluation of Energy Systems, Springer Briefs in Energy, Springer, 2012. (doi: 10.1007/978-1-4614-2242-6)

[30] Szargut, J.: Exergy Method - Technical and Ecological Applications, WIT Press, 2005.

[31] Dincer, I., Rosen, M. A.: Exergy, Energy, Environment and Sustainable Development, Second edition, Elsevier Ltd., 2013. 
[32] Bejan, A., Tsatsaronis, G., Moran, M.: Thermal Design and Optimization, Wiley, New York, 1995.

[33] Kotas, T.J.: The Exergy Method of Thermal Plant Analysis, Krieger Publishing Company, Malabar, 1995.

[34] Hafdhi, F., Khir, T., Ben Yahyia, A., Ben Brahim, A.: Energetic and exergetic analysis of a steam turbine power plant in an existing phosphoric acid factory, Energy Conversion and Management 106, p. 1230-1241, 2015. (doi: 10.1016/j.enconman.2015.10.044)

[35] Aljundi, I. H.: Energy and exergy analysis of a steam power plant in Jordan, Applied Thermal Engineering 29, p. 324-328, 2009. (doi: 10.1016/j.applthermaleng.2008.02.029)

[36] Ray, T.K., Datta, A., Gupta, A., Ganguly, R.: Exergy-based performance analysis for proper O\&M decisions in a steam power plant, Energy Conversion and Management 51, p. 1333-1344, 2010. (doi: 10.1016/j.enconman.2010.01.012)

[37] Lemmon, E. W., Huber, M. L., McLinden, M. O.: NIST Reference Fluid Thermodynamic and Transport Properties-REFPROP, Version 8.0, User's Guide, Colorado, 2007.

[38] Ahmadi, G.R., Toghraie, D.: Energy and exergy analysis of Montazeri Steam Power Plant in Iran, Renewable and Sustainable Energy Reviews 56, p. 454-463, 2016. (doi: 10.1016/j.rser.2015.11.074)

[39] Jokandan, M.J., Aghbashlo, M., Mohtasebi, S.S.: Comprehensive exergy analysis of an industrial-scale yogurt production plant, Energy 93, p. 1832-1851, 2015. (doi: 10.1016/j.energy.2015.10.003)

[40] Erdem, H.H., Akkaya, A.V., Cetin, B., Dagdas, A., Sevilgen, S.H., Sahin, B., Teke, I., Gungor, C., Atas, S.: Comparative energetic and exergetic performance analyses for coal-fired thermal power plants in Turkey, International Journal of Thermal Sciences 48, p. 2179-2186, 2009. (doi: 10.1016/j.ijthermalsci.2009.03.007)

[41] https://www.greisinger.de, (accessed: 20.06.2016.)

[42] http://www.industriascontrolpro.com, (accessed: 20.06.2016.)

[43] https://portal.endress.com, (accessed: 23.06.2016.)

[44] http://www.krtproduct.com, (accessed: 25.06.2016.)

Submitted: 27.07.2016. Vedran Mrzljak, vmrzljak@ riteh.hr

Accepted: $\quad$ 06.02.2017. Faculty of Engineering, University of Rijeka, Vukovarska 58, 51000 Rijeka, Croatia Igor Poljak, igor.poljak2@gmail.com

Rožići 4/3, 51221 Kostrena, Croatia

Vedran Medica-Viola, vmedica@riteh.hr

Faculty of Engineering, University of Rijeka, Vukovarska 58, 51000 Rijeka, Croatia 